\title{
Some effects of dopamine transporter and receptor ligands on discriminative stimulus, physiologic, and directly observable indices of opioid withdrawal in rhesus monkeys
}

\author{
Lance R. McMahon • Jun-Xu Li • F. Ivy Carroll • \\ Charles P. France
}

Received: 21 January 2008 / Accepted: 15 June 2008 / Published online: 18 July 2008

(C) Springer-Verlag 2008

\begin{abstract}
Rationale Some monoamine uptake inhibitors (e.g., cocaine) attenuate the subjective and discriminative stimulus effects of opioid withdrawal.

Objective This study examined a role for dopamine transporters and receptors as targets for drugs to modify the discriminative stimulus effects of opioid withdrawal and further examined a subset of these drugs for their capacity to modify some directly observable and physiologic indices of withdrawal.

Materials and methods Rhesus monkeys receiving $2 \mathrm{mg} /$ $\mathrm{kg}$ /day of $\mathrm{L}-\alpha$-acetylmethadol discriminated the opioid antagonist naltrexone $(0.0178 \mathrm{mg} / \mathrm{kg}$ s.c. $)$.

Results The naltrexone discriminative stimulus was attenuated not only by the $\mu$ agonist morphine but also by the dopamine $\mathrm{D}_{2}$-like receptor agonists bromocryptine and quinpirole. In contrast, the naltrexone discriminative stimulus was not consistently modified by the non-selective, $\mathrm{D}_{1^{-}}$and $\mathrm{D}_{2}$-like agonist apomorphine or by uptake inhibitors with high selectivity for dopamine transporters
\end{abstract}

\footnotetext{
L. R. McMahon · J.-X. Li • C. P. France $(\bowtie)$

Department of Pharmacology,

The University of Texas Health Science Center at San Antonio, 7703 Floyd Curl Drive,

San Antonio, TX 78229-3900, USA

e-mail: france@uthscsa.edu

C. P. France

Department of Psychiatry,

The University of Texas Health Science Center at San Antonio,

San Antonio, TX, USA

F. I. Carroll

Organic and Medicinal Chemistry, Research Triangle Institute, Research Triangle Park,

Durham, NC, USA
}

(GBR 12909, RTI 113, and RTI 177). In the same monkeys, naltrexone dose dependently decreased body temperature, increased breathing frequency, and induced directly observable signs (grimacing, salivation, and unusual posture). Hypothermia, hyperventilation, and signs of withdrawal were significantly attenuated by morphine and not by quinpirole.

Conclusions Attenuation of opioid withdrawal by $\mathrm{D}_{2}$-like receptor agonists that have lower efficacy than dopamine, and not by uptake inhibitors with selectivity for dopamine transporters, suggests that magnitude of receptor stimulation (e.g., efficacy) and selectivity at dopamine receptors are important factors in the modulation of opioid withdrawal. Attenuation of the naltrexone discriminative stimulus by drugs that inhibit both dopamine and serotonin uptake (e.g., cocaine) could result from an inhibitory effect of serotonin on dopamine. The role of dopamine in opioid withdrawal appears to be restricted to subjective (i.e., not somatic).

Keywords Dependence · Dopamine agonist · Drug discrimination $\cdot \mathrm{L}-\alpha$-Acetylmethadol $\cdot$ Naltrexone $\cdot$ Opioid . Rhesus monkey · Withdrawal

\section{Introduction}

Opioid dependence, evidenced by withdrawal upon discontinuation of use, is one factor limiting the clinical use of opioids and, further, contributes to abuse insofar as some dependent individuals use opioids to alleviate withdrawal. Monoamine neurotransmitters are involved in the behavioral effects of opioids and, in particular, appear to mediate some aspects of opioid dependence and withdrawal. For example, the directly observable signs of opioid withdrawal 
(e.g., sweating, tearing, and goose-flesh) are associated with increased norepinephrine neurotransmission in the locus coeruleus and activation of the sympathetic nervous system (Redmond and Krystal 1984); drugs that decrease norepinephrine (e.g., $\alpha_{2}$-autoreceptor agonist clonidine) can attenuate the somatic indices of opioid withdrawal (Gowing et al. 2002; Sell et al. 2005). However, clonidine does not alleviate the subjective effects of opioid withdrawal (Jasinski et al. 1985) and does not attenuate the discriminative stimulus effects of naltrexone in morphine-dependent animals (Holtzman 1985). Therefore, a neurotransmitter other than norepinephrine appears to mediate at least some of the symptoms of opioid withdrawal.

Extracellular dopamine levels in the ventral striatum are positively correlated with the reinforcing effects of opioids (Wise et al. 1995) and are inversely related to opioid withdrawal. For example, in dependent animals, dopamine levels decrease upon discontinuation of chronic opioid treatment or following administration of an antagonist (Acquas et al. 1991). A deficit in dopamine during opioid withdrawal might contribute to the use of cocaine both as a strategy for attenuating opioid withdrawal and for specifically achieving abstinence in a subset of opioid-dependent individuals (Hunt et al. 1984; Kosten and Kosten 1989; Rosen et al. 1992). Consistent with these clinical reports, cocaine markedly attenuates the discriminative stimulus effects of naltrexone in opioid-dependent monkeys, as well as the naltrexone-like discriminative stimulus effects of opioid abstinence (McMahon et al. 2004). Although many of the behavioral effects of cocaine appear to be mediated by inhibition of dopamine uptake, cocaine also inhibits serotonin and norepinephrine uptake (Koe 1976). Uptake inhibitors with some selectivity for serotonin or norepinephrine transporters are comparatively less effective than cocaine in attenuating the discriminative stimulus effects of naltrexone in opioid-dependent monkeys (Sell and France 2002), implicating a primary role for dopamine in these actions of cocaine.

To examine the role of dopamine and its receptors in the discriminative stimulus effects of opioid withdrawal, uptake inhibitors with selectivity for dopamine transporters and direct-acting agonists with varying selectivity for dopamine receptors were tested for their capacity to modify the discriminative stimulus of naltrexone in $\mathrm{L}-\alpha$-acetylmethadol (LAAM)-treated monkeys. Uptake inhibitors with selectivity for dopamine transporters were studied, including RTI 113 and RTI 177 (Kotian et al. 1995) as well as GBR 12909 (Heikkila and Manzino 1984). Dopamine receptor agonists also were studied, including the non-selective, $\mathrm{D}_{1}$ - and $\mathrm{D}_{2}$ like agonist apomorphine and the more selective $\mathrm{D}_{2}$-like receptor agonists bromocryptine and quinpirole (Jackson et al. 1988; Andersen and Jansen 1990). Based on previous reports that these drugs have positive reinforcing effects or cocaine-like discriminative stimulus effects in rhesus monkeys (Woolverton et al. 1984; Kleven et al. 1990; Sinnott et al. 1999; Wilcox et al. 2002; Lindsey et al. 2004; Kimmel et al. 2008), it was predicted that they might also share with cocaine the ability to attenuate the discriminative stimulus effects of opioid withdrawal. Some of the drugs (morphine and quinpirole) that attenuated the naltrexone discriminative stimulus were further examined for their capacity to modify other indices of opioid withdrawal including directly observable (grimacing, vocalization, and unusual postures) and physiologic signs (hypothermia and increased breathing frequency). By comparing the effects of a $\mathrm{D}_{2}$-like receptor agonist on discriminative and directly observable measures of opioid withdrawal, this study underscores the relative importance of $\mathrm{D}_{2}$-like receptors across various indices of opioid withdrawal.

\section{Materials and methods}

Subjects Three adult rhesus monkeys (Macaca mulatta, one male and two females, $5-8 \mathrm{~kg}$ ) were housed individually in stainless steel cages with free access to water. Monkeys received chow (High Protein Monkey Diet; Harlan Teklad, Madison, WI, USA) twice daily and fresh fruit following experimental sessions. Monkeys were maintained in accordance with the Institutional Animal Care and Use Committee, The University of Texas Health Science Center at San Antonio, and with the 1996 Guide for the Care and Use of Laboratory Animals (Institute of Laboratory Animal Resources on Life Sciences, National Research Council, National Academy of Sciences).

Apparatus Monkeys were seated in commercially available primate chairs (Model R001; Primate Products, Miami, FL, USA). During experimental sessions, monkeys were placed in ventilated, sound-attenuating operant chambers containing two response levers and a red light above each lever. Each chair was equipped with a pair of shoes containing brass electrodes to which a brief electric stimulus $(250 \mathrm{~ms}$, $3 \mathrm{~mA}$ ) could be delivered from an $\mathrm{A} / \mathrm{C}$ generator. Experimental procedures were controlled and data were collected by a computer and commercially available software (Med Associates, St. Albans, VT, USA).

Drug discrimination procedure Monkeys received LAAM $(1 \mathrm{mg} / \mathrm{kg})$ twice daily, $10 \mathrm{~h}$ apart, and were trained to discriminate naltrexone $(0.0178 \mathrm{mg} / \mathrm{kg})$ from saline in sessions beginning $8 \mathrm{~h}$ after the first daily LAAM injection. Each session consisted of 2-8, 15-min cycles. Each cycle began with a 10-min timeout, during which the chamber was dark and lever presses had no programmed consequence, followed by a 5-min response period, during which 
monkeys could respond under a fixed ratio (FR) 5 schedule of stimulus-shock termination. Under this schedule, illumination of the red lights signaled the delivery of an electric stimulus every $15 \mathrm{~s}$; five consecutive responses on the correct lever turned off the red lights and postponed the schedule for $30 \mathrm{~s}$ (i.e., initiated a timeout). The correct lever was designated by administration of saline or naltrexone $(0.0178 \mathrm{mg} / \mathrm{kg} \mathrm{s.c.})$ during the first minute of the cycle; assignments (e.g., left, saline; right, naltrexone) varied among monkeys and remained the same for an individual for the duration of the study. Responses on the incorrect lever reset the response requirement on the correct lever. Failure to satisfy the FR within $15 \mathrm{~s}$ resulted in the delivery of an electric stimulus; a maximum of four stimuli could be delivered per cycle. Training was conducted by administering saline or sham (i.e., dull pressure applied to the back) following a cycle in which naltrexone was administered, and 0-6 saline- or sham-injection cycles preceded the naltrexone-injection cycle. On some training days, monkeys received only saline or sham prior to each of two to eight cycles.

Animals had previously satisfied the criteria for testing defined as five consecutive or 6 of 7 days in which at least $80 \%$ of the total responses occurred on the lever designated as correct and fewer than five responses (one FR) occurred on the incorrect lever prior to completion of the first FR on the correct lever. For the current study, test drugs were administered every fourth day as long as performance during intervening training sessions satisfied the same criteria as above. Parameters for test sessions were the same as for training sessions except that five consecutive responses on either lever prevented delivery of the electrical stimulus and monkeys received naltrexone and other drugs alone or in combination. Naltrexone doseeffect curves were determined by administering saline at the beginning of the first cycle, followed by increasing doses of naltrexone in $0.5 \log$ unit increments at the beginning of subsequent cycles. Doses and pretreatment intervals for test compounds studied in combination with naltrexone were based upon preliminary studies conducted in this laboratory and from previous studies in other laboratories (i.e., Kimmel et al. 2008). The drugs were morphine (3.2-32 mg/kg), GBR 12909 (3.2 and $10 \mathrm{mg} / \mathrm{kg}$ ), RTI $113(0.1-1.0 \mathrm{mg} / \mathrm{kg})$, RTI $177(0.1$ and $0.32 \mathrm{mg} / \mathrm{kg})$, apomorphine $(0.032-1.0 \mathrm{mg} / \mathrm{kg})$, bromocryptine $(0.32-$ $3.2 \mathrm{mg} / \mathrm{kg})$, and quinpirole $(0.032-0.32 \mathrm{mg} / \mathrm{kg})$. A single dose was administered at the beginning of the first cycle (approximately $1 \mathrm{~h}$ before the smallest effective dose of naltrexone for producing discriminative stimulus effects); bromocryptine was administered $2 \mathrm{~h}$ before the first cycle. Naltrexone was administered up to doses producing at least $80 \%$ of responses on the naltrexone lever or up to $1.0 \mathrm{mg} / \mathrm{kg}$.
Direct observation of behavior and measurement of body temperature LAAM-treated monkeys discriminating naltrexone were seated in chairs and were observed by two experimenters blind to treatment. The temporal parameters for observation sessions were similar to discrimination sessions and comprised eight 15-min cycles ( $2 \mathrm{~h}$ total). Each cycle consisted of a 10-min pretreatment followed by a 2-min period during which the following signs were recorded as being present or absent: grimacing, salivation, shaking or rocking chair, and unusual posture (e.g., full extension of legs or arms for at least $3 \mathrm{~s}$ ). After the 2-min observation period, breathing frequency (number of exhalations) was determined from movement of the chest cavity for $15 \mathrm{~s}$. Monkeys were then assessed for the presence or absence of abdominal rigidity (hardening of abdominal muscles determined from palpation) and sensitivity to tactile stimulation (movement of arms or legs immediately upon palpation). Subsequently, temperature was measured by inserting a digital thermometer $10 \mathrm{~cm}$ into the rectum, and experimenters noted the presence or absence of uncooperativity while temperature was being recorded. Directly observable signs were summed, and the maximum possible score was 7 .

Eight observation sessions were conducted, and a minimum of 4 days elapsed between sessions. In the first and last sessions, saline was administered at the beginning of each cycle. In the remaining six sessions, monkeys received different treatments during a particular session and, for a particular monkey, treatment with naltrexone was alternated with saline across sessions. In three of these sessions, either saline, morphine $(10 \mathrm{mg} / \mathrm{kg})$, or quinpirole $(0.32 \mathrm{mg} / \mathrm{kg})$ was administered at the beginning of the first cycle followed by injections of saline administered in the remaining seven cycles. In three additional sessions, either saline, morphine $(10 \mathrm{mg} / \mathrm{kg})$, or quinpirole $(0.32 \mathrm{mg} / \mathrm{kg})$ was administered at the beginning of the first cycle followed by increasing doses $(0.001-1.0 \mathrm{mg} / \mathrm{kg})$ of naltrexone in subsequent cycles.

Drugs All drugs were administered s.c. in a volume of 0.1$1.0 \mathrm{ml}$, and doses were expressed as the weight of the forms indicated below. The compounds studied were LAAM, morphine sulphate, naltrexone hydrochloride, 1-(2-[bis(4fluorophenyl)methoxy]ethyl)-4-(3-phenylpropyl)piperazine (GBR 12909) (The Research Technology Branch, NIDA, Rockville, MD, USA), 3 $\beta$-(4-chlorophenyl)tropane-2 $\beta$ carboxylic acid phenyl ester hydrochloride (RTI 113; synthesized by F.I.C.), $3 \beta$-(4-chlorophenyl) tropane-2 $\beta$-(3phenylisoxazol-5-yl) hydrochloride (RTI 177; synthesized by F.I.C.), $S(+)$-apomorphine hydrochloride, 2-bromo- $\alpha$ ergocryptine methanesulfonate salt (bromocryptine), and quinpirole dihydrochloride (Sigma, St. Louis, MO, USA). LAAM was dissolved in a vehicle containing $77.5 \%$ sterile 
water, $15 \%$ emulphor, and $7.5 \%$ ethanol and was heated and sonicated. All other drugs were dissolved in sterile water or saline and were heated and sonicated as needed.

Data analyses Drug discrimination data were expressed as the percentage of the total number of responses that were made on the naltrexone lever (percent drug responding; percent DR) and were plotted as a function of dose. Response rate was calculated using total responses during illumination of lights (i.e., responses during timeouts were excluded). Response rate data were expressed as the percent of control response rate, defined as the average of the five saline training sessions in which animals passed the criteria for testing, and were plotted as a function of dose. The effects of naltrexone alone were determined 20 times throughout the course of this study, and these data were averaged among individual monkeys, and each monkey's average was used for further analyses. For discrimination studies, each dose of each test drug was studied once with increasing doses of naltrexone.

The dose of naltrexone to produce $50 \%$ responding on the drug-appropriate lever $\left(\mathrm{ED}_{50}\right.$ value $)$ and the $95 \%$ confidence limits were estimated using linear regression. The linear portion of the dose-effect curve was used, defined by doses producing $25 \%$ to $75 \%$ of the maximal effect, including not more than one dose producing $<25 \%$ and not more than one dose producing $>75 \%$ of the maximal effect. Other doses were excluded from the analyses. If naltrexone did not produce greater than $50 \%$ of responding on the drug-associated lever, then the largest dose (e.g., $1 \mathrm{mg} / \mathrm{kg}$ ) studied was assigned as the $\mathrm{ED}_{50}$ value. These values were determined first for individual monkeys and then averaged among all monkeys. $\mathrm{ED}_{50}$ values determined for naltrexone in combination with other drugs were considered significantly different from control (i.e., naltrexone alone) when the $95 \%$ confidence limits of the $\mathrm{ED}_{50}$ values did not overlap.

A one-way ANOVA for repeated measures was used to examine the effects of drugs alone on response rate; significant differences among treatments were examined with a Tukey-Kramer test $(p<0.05)$. To examine the combined effects of a dopamine ligand and naltrexone on response rate, the slopes and intercepts of naltrexone doseeffect curves alone and in combination with various doses of a dopamine ligand were compared with an $F$ ratio test using GraphPad. A dopamine ligand was considered to have significantly modified the effects of naltrexone on response rate when the data could not be described with a single line.

Body temperature (degree Celsius) was expressed as an average among monkeys $( \pm$ SEM) and was plotted as a function of dose or time after drug administration. Breathing frequency (breaths per $15 \mathrm{~s}$ multiplied by four and expressed as breaths per minute) for an individual monkey was calculated as an average of values obtained from two experimenters, and these values were then averaged among monkeys $( \pm$ SEM) and plotted as a function of time or dose. Behavioral signs (grimacing, salivation, excessive movement in the chair, unusual posture, abdominal rigidity, sensitivity to tactile stimulation, and uncooperativity) were calculated as an average of measurements obtained from two experimenters. A score of 1 was given when a sign was present during a 2-min observation period. Signs (maximum 7) were averaged among monkeys $( \pm$ SEM) and were plotted as a function of time or dose. Body temperature, breathing frequency, and signs were analyzed with separate two-way ANOVAs for repeated measures, with one factor consisting of pretreatment (saline, $10 \mathrm{mg} / \mathrm{kg}$ of morphine, and $0.32 \mathrm{mg} / \mathrm{kg}$ of quinpirole) and a second factor consisting of time (15$120 \mathrm{~min})$ or dose $(0.001-1.0 \mathrm{mg} / \mathrm{kg})$ of naltrexone. A post hoc Tukey-Kramer test was used to examine significant differences among treatments.

\section{Results}

Effects of morphine and direct-acting dopamine agonists on discriminative stimulus effects of naltrexone Naltrexone increased responding on the drug lever in a dose-related manner with a dose of $0.01 \mathrm{mg} / \mathrm{kg}$ occasioning predominantly naltrexone-lever responding in all three LAAMtreated monkeys (Figs. 1 and 2, top, closed circles). The $\mathrm{ED}_{50}$ value $(95 \%$ confidence limits) for naltrexone was $0.0059(0.0054-0.0064) \mathrm{mg} / \mathrm{kg}$ (Table 1). Administration of saline during the first cycle occasioned predominantly saline-appropriate responding (Figs. 1 and 2, top, V). Under control conditions, doses of naltrexone up to $0.01 \mathrm{mg} / \mathrm{kg}$ did not modify response rate. Morphine (3.2$32 \mathrm{mg} / \mathrm{kg}$ ) produced exclusively vehicle-lever responding and, when administered in combination with naltrexone, attenuated the naltrexone discriminative stimulus (Fig. 1, top left). For example, 10 and $32 \mathrm{mg} / \mathrm{kg}$ of morphine significantly increased the $\mathrm{ED}_{50}$ value of naltrexone 3.2and 6.8-fold, respectively (Table 1). Rate of responding was not significantly modified by morphine alone or in combination with naltrexone at the doses studied (Fig. 1, bottom left).

The $\mathrm{D}_{2}$-like receptor agonists bromocryptine $(0.32$ $3.2 \mathrm{mg} / \mathrm{kg})$ and quinpirole $(0.032-0.32)$ produced a maximum average $( \pm \mathrm{SEM})$ of $7( \pm 7) \%$ of responses on the naltrexone lever. The discriminative stimulus effects of naltrexone were significantly attenuated by bromocryptine and quinpirole (Fig. 1, top middle and right). For example, doses of 1 and $3.2 \mathrm{mg} / \mathrm{kg}$ of bromocryptine increased the $\mathrm{ED}_{50}$ value of naltrexone 6.9 - and 83 -fold, respectively; 

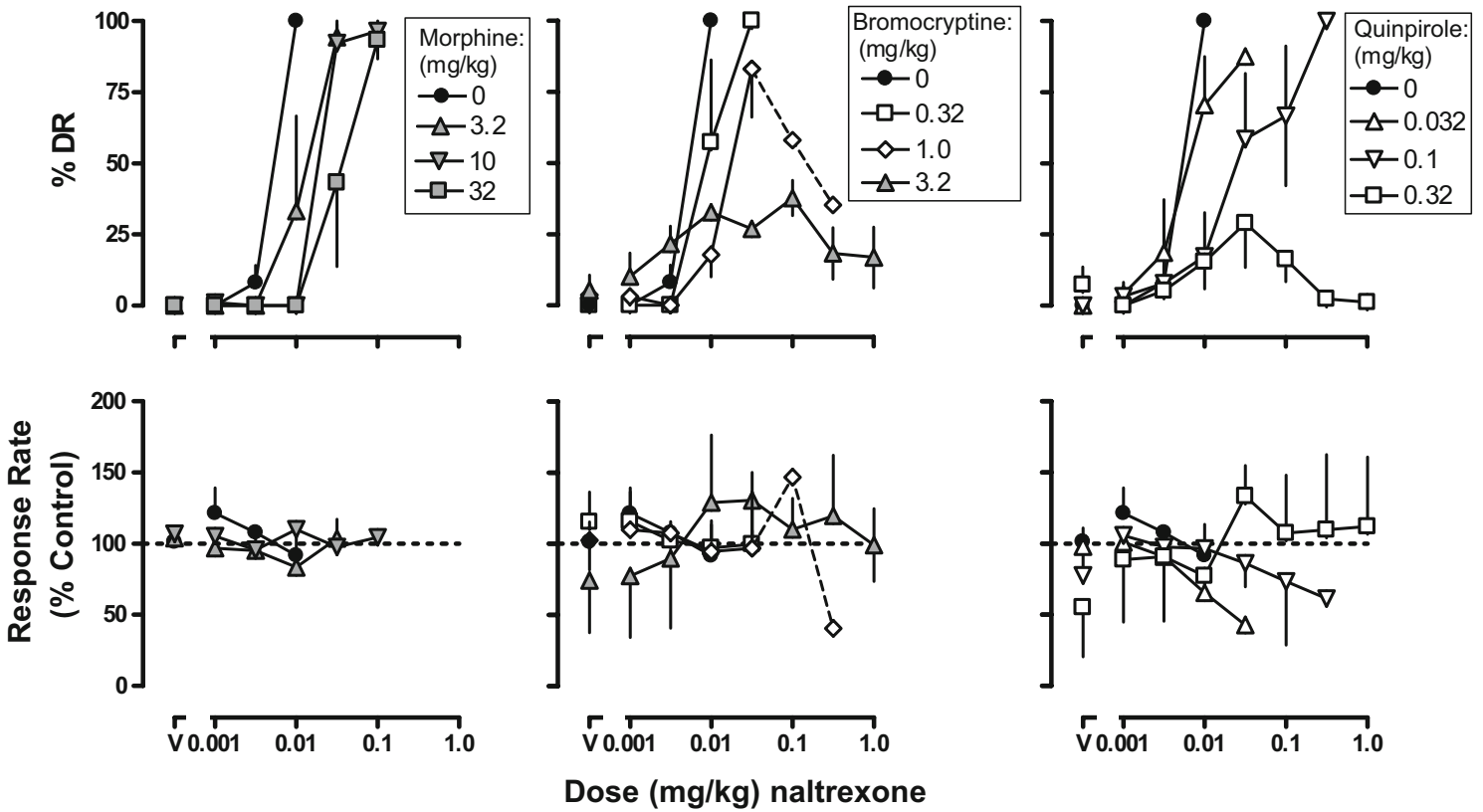

Fig. 1 Discriminative stimulus effects of naltrexone (top) and rate of responding (bottom) in LAAM-treated monkeys that received morphine, bromocryptine, or quinpirole. Abscissae Dose in milligrams per kilogram body weight; vehicle $(V)$ or a dose of drug was administered in the first cycle. Ordinates Mean $( \pm$ SEM) percentage of responding

on the drug-appropriate lever ( $\% D R$ drug responding, top) and mean response rate expressed as percentage of control (saline training days) rate [response rate (\% control), bottom] from three monkeys. Dashed lines in middle panels represent data from one monkey

doses of 0.1 and $0.32 \mathrm{mg} / \mathrm{kg}$ of quinpirole increased the $\mathrm{ED}_{50}$ value of naltrexone 7.6- and 95-fold, respectively (Table 1). While bromocryptine and quinpirole tended to modify rate of responding in some monkeys, these effects were not observed in all monkeys and were not statistically significant (Fig. 1, bottom middle and right).

Uptake inhibitors with selectivity for dopamine transporters, including GBR 12909 (3.2 and $10 \mathrm{mg} / \mathrm{kg}$ ), RTI 113 $(0.1-1.0 \mathrm{mg} / \mathrm{kg})$, and RTI $177(0.1$ and $0.32 \mathrm{mg} / \mathrm{kg})$ produced less than $2 \%$ responding on the naltrexone lever (Fig. 2, top three leftmost panels, V). The non-selective $\mathrm{D}_{1}$ and $\mathrm{D}_{2}$-like receptor agonist apomorphine also produced
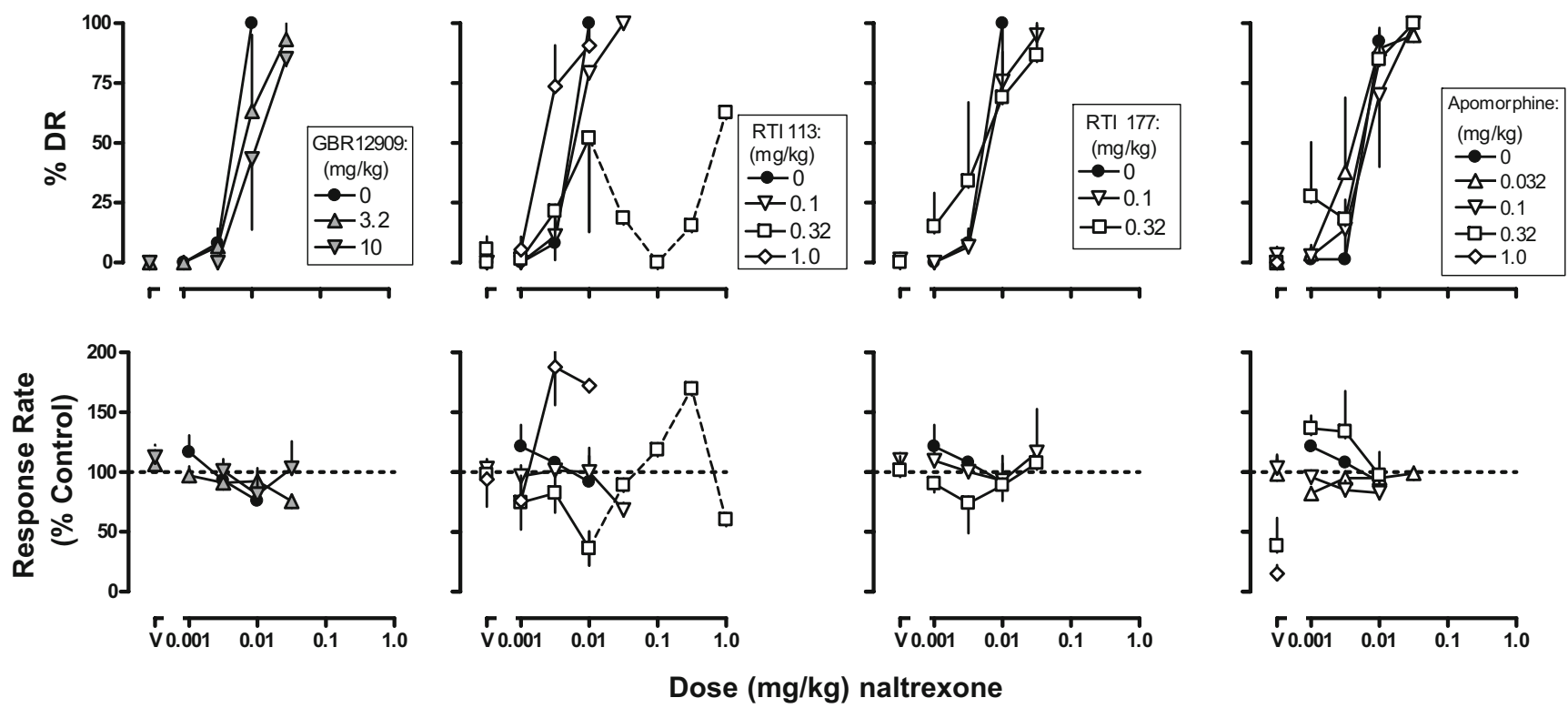

Dose $(\mathrm{mg} / \mathrm{kg})$ naltrexone

Fig. 2 Discriminative stimulus effects of naltrexone (top) and rate of responding (bottom) in LAAM-treated monkeys that received GBR 12909, RTI 113, RTI 177, or apomorphine. See legend to Fig. 1 for other details 
Table 1 Mean $\mathrm{ED}_{50}$ values and $95 \%$ confidence limits for the naltrexone discrimination dose-effect curve under control conditions and after pretreatment with morphine, bromocryptine, quinpirole, GBR 12909, RTI 113, RTI 177, and apomorphine

\begin{tabular}{|c|c|c|}
\hline \multirow[t]{2}{*}{ Drug dose } & \multicolumn{2}{|c|}{ Naltrexone discriminative stimulus } \\
\hline & $\mathrm{ED}_{50}$ value & $95 \%$ confidence limits \\
\hline Control & 0.0059 & $(0.0054-0.0064)$ \\
\hline \multicolumn{3}{|l|}{ +Morphine } \\
\hline $3.2 \mathrm{mg} / \mathrm{kg}$ & 0.014 & $(0.0057-0.027)$ \\
\hline $10 \mathrm{mg} / \mathrm{kg}$ & $0.019^{\mathrm{a}}$ & $(0.017-0.021)$ \\
\hline $32 \mathrm{mg} / \mathrm{kg}$ & $0.040^{\mathrm{a}}$ & $(0.017-0.073)$ \\
\hline \multicolumn{3}{|l|}{ +Bromocryptine } \\
\hline $0.32 \mathrm{mg} / \mathrm{kg}$ & 0.011 & $(0.0050-0.018)$ \\
\hline $1 \mathrm{mg} / \mathrm{kg}$ & $0.041^{\mathrm{a}}$ & $(0.0074-0.093)$ \\
\hline $3.2 \mathrm{mg} / \mathrm{kg}$ & $0.49^{\mathrm{a}}$ & $(0.41-0.59)$ \\
\hline \multicolumn{3}{|l|}{ +Quinpirole } \\
\hline $0.032 \mathrm{mg} / \mathrm{kg}$ & 0.0073 & $(0.0026-0.014)$ \\
\hline $0.1 \mathrm{mg} / \mathrm{kg}$ & $0.045^{\mathrm{a}}$ & $(0.0071-0.12)$ \\
\hline $0.32 \mathrm{mg} / \mathrm{kg}$ & $0.56^{\mathrm{a}}$ & $(0.54-0.57)$ \\
\hline \multicolumn{3}{|l|}{ +GBR 12909} \\
\hline $3.2 \mathrm{mg} / \mathrm{kg}$ & 0.015 & $(0.0035-0.020)$ \\
\hline $10 \mathrm{mg} / \mathrm{kg}$ & 0.013 & $(0.0056-0.024)$ \\
\hline \multicolumn{3}{|l|}{ +RTI 113} \\
\hline $0.1 \mathrm{mg} / \mathrm{kg}$ & 0.0059 & $(0.0045-0.0074)$ \\
\hline $0.32 \mathrm{mg} / \mathrm{kg}$ & 0.0059 & $(0.00095-2.2)$ \\
\hline $1 \mathrm{mg} / \mathrm{kg}$ & 0.0027 & $(0.0012-0.0050)$ \\
\hline \multicolumn{3}{|l|}{ +RTI 177} \\
\hline $0.1 \mathrm{mg} / \mathrm{kg}$ & 0.0075 & $(0.0057-0.0097)$ \\
\hline $0.32 \mathrm{mg} / \mathrm{kg}$ & 0.011 & $(0.00094-0.033)$ \\
\hline \multicolumn{3}{|l|}{+ Apomorphine } \\
\hline $0.032 \mathrm{mg} / \mathrm{kg}$ & 0.0046 & $(0.0017-0.0091)$ \\
\hline $0.1 \mathrm{mg} / \mathrm{kg}$ & 0.0086 & $(0.0027-0.017)$ \\
\hline $0.32 \mathrm{mg} / \mathrm{kg}$ & 0.0057 & $(0.0051-0.0064)$ \\
\hline $1 \mathrm{mg} / \mathrm{kg}$ & $-{ }^{\mathrm{b}}$ & \\
\hline
\end{tabular}

${ }^{\mathrm{a}}$ Greater than control $\mathrm{ED}_{50}$ value

${ }^{\mathrm{b}}$ Not determined due to disruption in operant responding

less than $2 \%$ responding on the naltrexone lever (Fig. 2, rightmost panel, V). Although GBR 12909 and RTI 113 attenuated the naltrexone discriminative stimulus in at least one monkey, neither drug significantly modified the group average $\mathrm{ED}_{50}$ value of naltrexone (Table 1). The $\mathrm{ED}_{50}$ value of naltrexone also was not significantly modified by RTI 177 and apomorphine. Response rate was not significantly altered by the uptake inhibitors, alone or in combination with naltrexone (Fig. 2, bottom leftmost panels). When administered alone, apomorphine markedly decreased rate of responding $(p<0.01)$, i.e., average $( \pm$ SEM) rate of responding was $15( \pm 7) \%$ of control at a dose of $1.0 \mathrm{mg} / \mathrm{kg}$ (Fig. 2, rightmost panel, V). Response rate was not significantly modified by apomorphine in combination with naltrexone.
Effects of morphine and quinpirole on directly observable and physiologic indices of LAAM withdrawal Body temperature (degree Celsius), respiration (breaths per minute), and directly observable signs were examined for $2 \mathrm{~h}$ following administration of saline, morphine $(10 \mathrm{mg} / \mathrm{kg})$, and quinpirole $(0.32 \mathrm{mg} / \mathrm{kg}$; Fig. 3, top). When administered alone, morphine and quinpirole decreased body temperature slightly (Fig. 3, top left), although these effects were not significant at the $p<0.05$ level. Body temperature decreased over time $[F(7,14)=12.82, p<0.05]$, an effect most evident with morphine and quinpirole treatment, although there was no significant interaction between drug and time. There was no significant effect of drug or time on respiratory frequency (Fig. 3, top middle), nor was there a significant interaction between drug treatment and time. There was a significant interaction between drug and time $[F(14,28)=3.35, p<0.05]$ on directly observable signs due to an effect of quinpirole to increase some signs (Fig. 3, top right). Signs induced by quinpirole included excessive movement in the chair and unusual posture in all monkeys and abdominal rigidity and sensitivity to tactile stimulation in one of three monkeys. Signs did not vary significantly as a function of drug or time.

Naltrexone dose dependently decreased body temperature $[F(7,14)=36.63, p<0.05]$, increased respiration $[F(7$, $14)=38.66, p<0.05]$, and increased directly observable signs $[F(7,14)=15.77, p<0.05$; Fig. 3 , bottom]. The maximum decrease in body temperature was $1.7^{\circ} \mathrm{C}$ (from 38.5 to $36.8^{\circ} \mathrm{C}$ ) at $0.1-1.0 \mathrm{mg} / \mathrm{kg}$ of naltrexone, and the maximum increase in respiration was 41 breaths per minute (from 26 to 67 breaths per minute) at $0.032-1.0 \mathrm{mg} / \mathrm{kg}$ of naltrexone (Fig. 3, bottom left and middle). All seven signs were observed after at least one dose of naltrexone in all three LAAM-treated monkeys, and the maximum score $( \pm$ SEM) of $4.7( \pm 0.2)$ was evident at $0.032 \mathrm{mg} / \mathrm{kg}$ of naltrexone and remained elevated up to a dose of $1.0 \mathrm{mg} / \mathrm{kg}$ (Fig. 3, bottom right).

Quinpirole significantly enhanced $[F(2,4)=8.01$, $p<0.05]$ the hypothermic effects of naltrexone (Fig. 3, bottom left); in contrast, morphine significantly attenuated $[F(14,28)=3.94, p<0.05]$ the hypothermic effects of naltrexone. There was no significant main effect of drug pretreatment, although there was a significant interaction between drug pretreatment and naltrexone dose $[F(14$, $28)=2.72, p<0.05]$ because morphine attenuated hyperventilation induced by naltrexone (Fig. 3, bottom middle). For directly observable signs, there was an effect of drug pretreatment $[F(2,4)=18.59, p<0.05]$ that was due to morphine, and not quinpirole, significantly attenuating the effects of all doses of naltrexone (Fig. 3, bottom right), as evidenced by the absence of a significant interaction between pretreatment drug and naltrexone dose. 

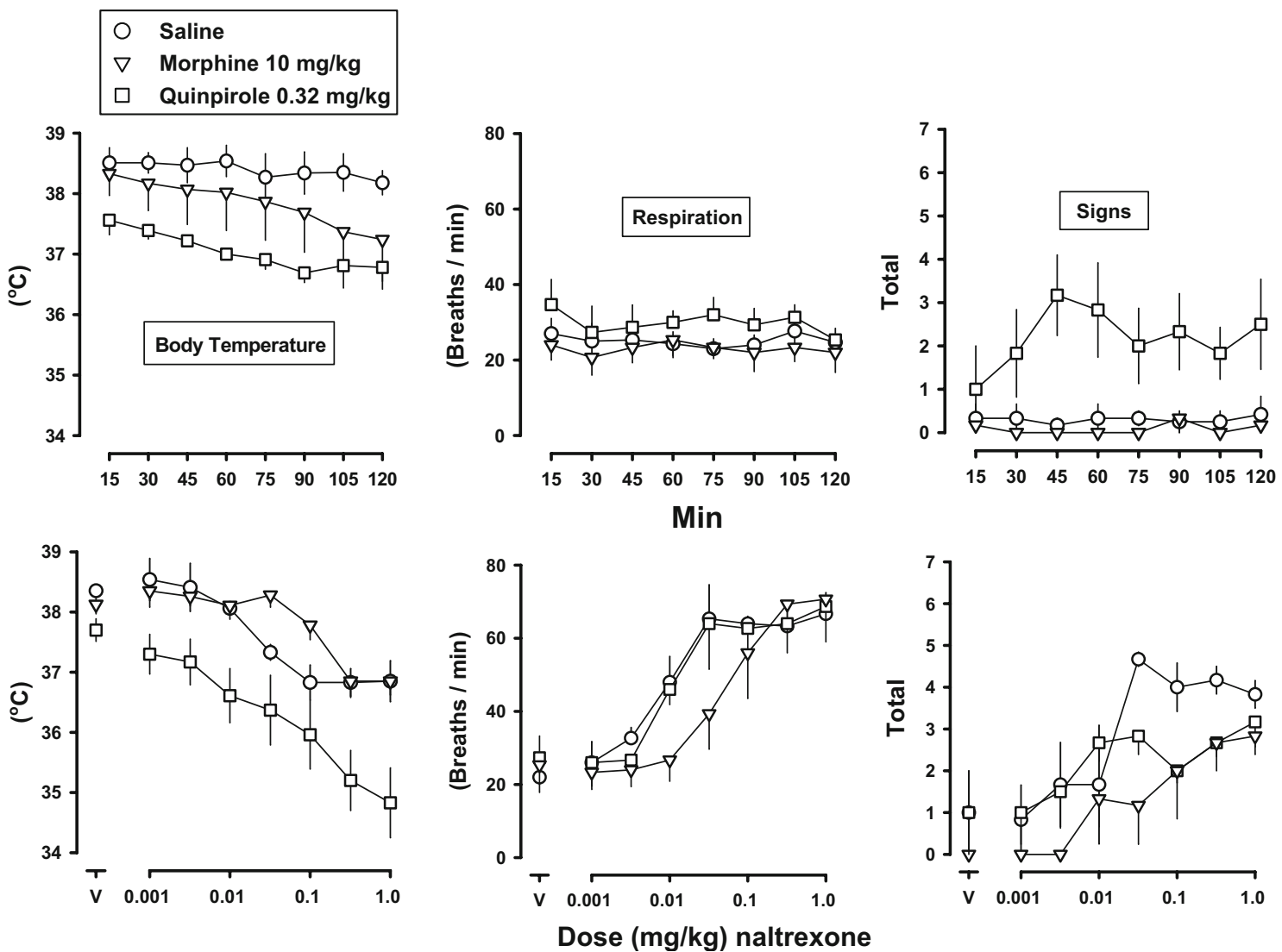

Fig. 3 Effects of morphine and quinpirole alone (top) and in combination with naltrexone (bottom) on body temperature (left), respiration (middle), and directly observable signs of withdrawal (right). Abscissae Time in minutes (top) and dose in milligrams per kilogram body weight (bottom); vehicle $(V)$, morphine $(10 \mathrm{mg} / \mathrm{kg}$ ), and quinpirole $(0.32 \mathrm{mg} / \mathrm{kg})$ were administered in the first cycle. Ordinates Mean ( \pm SEM) body temperature (degree Celsius, left), respiration (breaths per minute, middle), and directly observable signs (total, right) for three monkeys. The top panel shows the effects of vehicle, morphine $(10 \mathrm{mg} / \mathrm{kg})$, and quinpirole $(0.32 \mathrm{mg} / \mathrm{kg})$ alone every $15 \mathrm{~min}$ during the 2 -h session. The bottom panel shows the effects of vehicle, morphine $(10 \mathrm{mg} / \mathrm{kg})$, and quinpirole $(0.32 \mathrm{mg} / \mathrm{kg})$ alone ( $V$; i.e., after $15 \mathrm{~min}$ ) and in combination with cumulative doses of naltrexone $(0.001-1 \mathrm{mg} / \mathrm{kg})$ administered every $15 \mathrm{~min}$ during the 2-h session

\section{Discussion}

Cocaine can attenuate the subjective effects of opioid withdrawal in humans (Hunt et al. 1984; Kosten and Kosten 1989; Rosen et al. 1992). Cocaine also attenuates the discriminative stimulus effects of naltrexone in monkeys treated with LAAM $(2 \mathrm{mg} / \mathrm{kg} / \mathrm{day}$; Sell and France 2002) and, to a lesser extent, morphine (3.2 mg/ $\mathrm{kg} /$ day; McMahon et al. 2004). To examine the role of dopamine transporters and receptors in the discriminative stimulus effects of opioid withdrawal, dopamine uptake inhibitors and direct-acting receptor agonists were studied for their capacity to modify a naltrexone discriminative stimulus in LAAM-treated monkeys. Morphine and dopamine $\mathrm{D}_{2}$-like receptor agonists (bromocryptine and quinpirole) attenuated the discriminative stimulus effects of naltrexone, whereas the non-selective, $\mathrm{D}_{1^{-}}$and $\mathrm{D}_{2}$-like receptor agonist apomorphine, as well as uptake inhibitors with selectivity for dopamine transporters (GBR 12909, RTI 113, and RTI 177), did not consistently modify the naltrexone discriminative stimulus. Whereas morphine also attenuated directly observable and physiologic indices (e.g., hypothermia and hyperventilation) of naltrexone-induced withdrawal, quinpirole did not attenuate these indices of withdrawal. These results suggest that stimulation of $\mathrm{D}_{2}$ like receptors attenuates the subjective and not other indices (i.e., directly observable) of opioid withdrawal, whereas inhibition of dopamine uptake alone does not mimic these effects of $\mathrm{D}_{2}$-receptor agonists.

Attenuation of the discriminative stimulus effects of naltrexone in LAAM-treated monkeys by quinpirole and bromocryptine underscores the likely importance of $\mathrm{D}_{2}$-like receptors in opioid dependence, in general, and suggests that agonism at these receptors can alleviate the subjective effects of withdrawal, in particular. Previous studies also implicated an important role for $\mathrm{D}_{2}$-like receptors in 
mediating some indices of opioid withdrawal. For example, in opioid-dependent rodents, conditioned place aversion develops with antagonists at $\mathrm{D}_{2}$-like receptors at doses that do not produce place conditioning in non-dependent rodents (Funada and Shippenberg 1996). $\mathrm{D}_{2}$-like antagonists also enhance the discriminative stimulus effects of naltrexone in LAAM-treated monkeys (Sell and France 2002). In rats, the locomotor stimulating actions of $D_{2}$-like receptor agonists (including quinpirole) are enhanced during opioid withdrawal, and the expression of immediate early genes in the ventral striatum during opioid withdrawal is attenuated by $\mathrm{D}_{2}$-like agonists (Druhan et al. 2000). The clinical literature also supports a relationship between $\mathrm{D}_{2}$ like receptors and heroin use among methadone-maintained individuals inasmuch as relapse is associated with a polymorphism in a gene coding for $\mathrm{D}_{2}$-like receptors (Lawford et al. 2000; but see Barratt et al. 2006). Collectively, these data suggest that $\mathrm{D}_{2}$-like receptors are viable targets for modulating some aspects of opioid dependence and withdrawal.

Uptake inhibitors acting selectively at dopamine transporters (GBR 12909, RTI 113, and RTI 177) did not attenuate the discriminative stimulus effects of naltrexone. These results contrast the striking effect of cocaine in attenuating the naltrexone discriminative stimulus in these same monkeys (Sell and France 2002). GBR 12909, RTI 113, and RTI 177 can share behavioral effects (i.e., discriminative stimulus effects) with cocaine (Kleven et al. 1990; Howell et al. 2000; Cook et al. 2002; Kimmel et al. 2008), whereas monoamine uptake inhibitors with little or no affinity at dopamine transporters are much less likely to share discriminative stimulus effects with cocaine. Thus, under some conditions, dopamine uptake inhibition appears to be primarily responsible for the qualitatively similar effects of dopamine transporter ligands that vary in affinity at serotonin and norepinephrine transporters. Monoamine uptake inhibitors with little or no affinity for dopamine transporters (e.g., imipramine) modestly attenuate the naltrexone discriminative stimulus (Sell and France 2002). Moreover, uptake inhibitors with selectivity for serotonin transporters are reported to attenuate opioid withdrawal (Gray 2002). Therefore, inhibition of both dopamine and other monoamine transport appears to produce greater attenuation of withdrawal than inhibition of dopamine transport alone.

Unlike quinpirole and bromocryptine, apomorphine did not attenuate the naltrexone discriminative stimulus in LAAM-treated monkeys. Apomorphine binds non-selectively to $D_{1}$ - and $D_{2}$-like receptors and appears to have lower agonist efficacy at $\mathrm{D}_{1}$-like receptors than at $\mathrm{D}_{2}$-like receptors (Kebabian and Calne 1979). In rhesus monkeys, the discriminative stimulus effects of apomorphine were appar- ently mediated by $\mathrm{D}_{2}$-like receptors (Woolverton et al. 1987; Tang and Code 1989). In rodents, $\mathrm{D}_{1}$-like receptors were reported to play a role in opioid dependence (Chartoff et al. 2006), and apomorphine might be acting at $D_{1}$-like receptors in opioid-dependent animals. For example, although apomorphine attenuated some directly observable signs of opioid withdrawal (Cox et al. 1976; Tseng et al. 1976), apomorphine and quinpirole had qualitatively different effects on signs of opioid withdrawal (Zarrindast et al. 2002), perhaps reflecting some activity of apomorphine at $\mathrm{D}_{1}$-like receptors. Other studies indicate that apomorphine acts at $\mathrm{D}_{1}$-like receptors in opioid-dependent animals. For example, non-competitive $\mathrm{N}$ methyl-D-aspartate (NMDA) antagonists attenuated opioid dependence, apomorphine enhanced the effects of NMDA antagonists, and the effects of apomorphine were attenuated by $D_{1}$ - and not $D_{2}$-like antagonists (Farzin 1999). The extent to which $\mathrm{D}_{1}$-like receptors mediate the discriminative stimulus effects of naltrexone in opioid-dependent monkeys remains to be established.

Whereas cocaine and $\mathrm{D}_{2}$-like receptor agonists attenuated the naltrexone discriminative stimulus, inhibitors with selectivity for dopamine transporters did not. This seemingly paradoxical outcome could be related to differences in pharmacologic selectivity and dopamine receptor efficacy among the drugs and to a non-monotonic function that describes the relationship between dopamine signaling and attenuation of opioid withdrawal. For example, an intermediate level of $\mathrm{D}_{2}$-like receptor stimulation might be optimal for attenuating opioid withdrawal, whereas relatively high levels of $\mathrm{D}_{2}$-like receptor stimulation might be relatively ineffective. This hypothesis assumes that dopamine and dopamine transporter-selective drugs (GBR 12909, RTI 113 , and RTI 177) produce the highest level of $\mathrm{D}_{2}$-like receptor stimulation inasmuch as dopamine has high intrinsic activity (agonist efficacy) at $\mathrm{D}_{2}$-like receptors (Geurts et al. 1999). The relatively low agonist efficacy of direct-acting $\mathrm{D}_{2}$-like receptor agonists (quinpirole and bromocryptine; Geurts et al. 1999) might be responsible for their greater opioid withdrawal-attenuating effects as compared to higher efficacy ligands (dopamine and inhibitors of dopamine uptake). Relatively less activation of dopamine receptors might also result from a loss of pharmacologic selectivity (i.e., cocaine). For example, concurrent inhibition of dopamine and serotonin uptake might result in less stimulation of dopamine receptors than that resulting from inhibition of dopamine uptake alone inasmuch as serotonin inhibits mesoaccumbens dopamine activity (Dewey et al. 1995). Attenuation of opioid withdrawal could be most effective at an intermediate level of $\mathrm{D}_{2}$-like receptor stimulation, thereby accounting for the differential effectiveness of drugs that vary in the degree to which they activate those receptors. 
In LAAM-treated monkeys, naltrexone produced signs of withdrawal (i.e., hypothermia, hyperventilation, and other directly observable signs) that were similar to those reported previously in morphine-dependent rhesus monkeys that were freely moving (i.e., in their home cage; Katz 1986) or seated in a chair (Holtzman and Villarreal 1969; Paronis and Woods 1997). Morphine attenuated both discriminative measures and signs of opioid withdrawal; quinpirole attenuated the former and not the latter and mimicked some measures of opioid withdrawal (hypothermia), consistent with its well-documented actions to decrease body temperature (e.g., Faunt and Crocker 1989). Previous studies in rodents reported that dopamine $\mathrm{D}_{2}$-like receptor agonists attenuate signs of opioid withdrawal (Gomaa et al. 1989; Zarrindast et al. 2002; Walters et al. 2000). Attenuation of discriminative stimulus and not other indices of opioid withdrawal might reflect a greater sensitivity of drug discrimination measures, relative to other measures, and it is possible that signs of opioid withdrawal are modified by quinpirole at doses larger than $0.32 \mathrm{mg} / \mathrm{kg}$. That the effects of clonidine on these various measures were opposite to those of quinpirole (i.e., clonidine attenuated directly observable signs and not the naltrexone discriminative stimulus; Sell and France 2002; Sell et al. 2005) suggests that differential sensitivity among these dependent measures is not responsible for the present results. Rather, $\mathrm{D}_{2}$-like receptor agonism modifies the subjective and not the directly observable indices of opioid withdrawal.

In summary, the results of these studies demonstrate that agonism at $\mathrm{D}_{2}$-like dopamine receptors can attenuate the discriminative stimulus effects of naltrexone in LAAMtreated monkeys without modifying directly observable and physiologic indices of withdrawal. Uptake inhibitors acting selectively at dopamine transporters, in contrast to cocaine that acts at several different monoamine transporters, did not modify the naltrexone discriminative stimulus; this finding suggests that inhibition of uptake at dopamine transporters is not sufficient to attenuate the discriminative stimulus (and, perhaps, subjective) effects of opioid withdrawal. Therefore, in addition to dopamine uptake inhibition and stimulation of $\mathrm{D}_{2}$-like receptors, other mechanisms (serotonin and norepinephrine uptake inhibition) appear to contribute to the mechanism by which cocaine alleviates subjective indices of opioid withdrawal. Drugs that target one (i.e., $\mathrm{D}_{2}$-like receptors) or multiple components (i.e., dopamine and serotonin transporters) of the various mechanisms of action of cocaine might provide novel pharmacologic strategies for alleviating the subjective experience of opioid withdrawal. However, the effects of some of these drugs (quinpirole) to mimic or enhance some signs of opioid withdrawal (i.e., hypothermia) could limit therapeutic utility.
Acknowledgements This work was supported by the United States Public Health Service Grant DA05018. C.P.F. is the recipient of a Senior Scientist Award (K05 DA17918) from the National Institute on Drug Abuse. The content is solely the responsibility of the authors and does not necessarily represent the official views of the National Institute on Drug Abuse or the National Institutes of Health. The authors thank A. Gaylor, H. Jasso, R. Jimenez, E. Quarve, and K. Stone for providing technical assistance.

\section{References}

Acquas E, Carboni E, Di Chiara G (1991) Profound depression of mesolimbic dopamine release after morphine withdrawal in dependent rats. Eur J Pharmacol 193:133-134

Andersen PH, Jansen JA (1990) Dopamine receptor agonists: selectivity and dopamine $\mathrm{D}_{1}$ receptor efficacy. Eur J Pharmacol 188:335-347

Barratt DT, Coller JK, Somogyi AA (2006) Association between the $\mathrm{DRD}_{2} \mathrm{~A} 1$ allele and response to methadone and buprenorphine maintenance treatments. Am J Med Genet B Neuropsychiatr Genet 141:323-331

Chartoff EH, Mague SD, Barhight MF, Smith AM, Carlezon WA (2006) Behavioral and molecular effects of dopamine $\mathrm{D}_{1}$ receptor stimulation during naloxone-precipitated morphine withdrawal. J Neurosci 26:6450-6457

Cook CD, Carroll FI, Beardsley PM (2002) RTI 113, a 3-phenyltropane analog, produces long-lasting cocaine-like discriminative stimulus effects in rats and squirrel monkeys. Eur J Pharmacol 442:93-98

Cox B, Ary M, Lomax P (1976) Changes in sensitivity to apomorphine during morphine dependence and withdrawal in rats. J Pharmacol Exp Ther 196:637-641

Dewey SL, Smith GS, Logan J, Alexoff D, Ding YS, King P, Pappas N, Brodie JD, Ashby CR (1995) Serotonergic modulation of striatal dopamine measured with positron emission tomography (PET) and in vivo microdialysis. J Neurosci 15:821-829

Druhan JP, Walters CL, Aston-Jones G (2000) Behavioral activation induced by $\mathrm{D}_{2}$-like receptor stimulation during opiate withdrawal. J Pharmacol Exp Ther 294:531-538

Farzin D (1999) Modification of naloxone-induced withdrawal signs by dextromethorphan in morphine-dependent mice. Eur $\mathrm{J}$ Pharmacol 377:35-42

Faunt JE, Crocker AD (1989) The effects of selective dopamine receptor agonists and antagonists on body temperature in rats. Eur J Pharmacol 133:243-247

Funada M, Shippenberg TS (1996) Differential involvement of $D_{1}$ and $\mathrm{D}_{2}$ dopamine receptors in the expression of morphine withdrawal signs in rats. Behav Pharmacol 7:448-453

Geurts M, Hermans E, Cumps J, Maloteaux JM (1999) Dopamine receptor-modulated [35S]GTPgammaS binding in striatum of 6hydroxydopamine-lesioned rats. Brain Res 841:135-142

Gomaa AA, Mohamed LH, Ahmed HN (1989) Modification of morphine-induced analgesia, tolerance and dependence by bromocriptine. Eur J Pharmacol 170:129-35

Gowing LR, Farrell M, Ali RL, White JM (2002) Alpha ${ }_{2}$-adrenergic agonists in opioid withdrawal. Addiction 97:49-58

Gray AM (2002) The effect of fluvoxamine and sertraline on the opioid withdrawal syndrome: a combined in vivo cerebral microdialysis and behavioural study. Eur Neuropsychopharmacol $12: 245-254$

Heikkila RE, Manzino L (1984) Behavioral properties of GBR 12909, GBR 13069 and GBR 13098: specific inhibitors of dopamine uptake. Eur J Pharmacol 103:241-248 
Holtzman SG (1985) Discriminative stimulus effects of morphine withdrawal in the dependent rat: suppression by opiate and nonopiate drugs. J Pharmacol Exp Ther 233:80-86

Holtzman SG, Villarreal JE (1969) Morphine dependence and body temperature in rhesus monkeys. J Pharmacol Exp Ther 166:125-133

Howell LL, Czoty PW, Kuhar MJ, Carrol FI (2000) Comparative behavioral pharmacology of cocaine and the selective dopamine uptake inhibitor RTI-113 in the squirrel monkey. J Pharmacol Exp Ther 292:521-529

Hunt DE, Lipton DS, Goldsmith D, Strug D (1984) Street pharmacology: uses of cocaine and heroin in the treatment of addiction. Drug Alcohol Depend 13:375-387

Jackson DM, Jenkins OF, Ross SB (1988) The motor effects of bromocriptine - a review. Psychopharmacology 95:433-446

Jasinski DR, Johnson RE, Kocher TR (1985) Clonidine in morphine withdrawal. Differential effects on signs and symptoms. Arch Gen Psychiatry 42:1063-1066

Katz JL (1986) Effects of clonidine and morphine on opioid withdrawal in rhesus monkeys. Psychopharmacology 88:392-397

Kebabian JW, Calne DB (1979) Multiple receptors for dopamine. Nature 277:93-96

Kimmel HL, Negus SS, Wilcox KM, Ewing SB, Stehouwer J, Goodman MM, Votaw JR, Mello NK, Carroll FI, Howell LL (2008) Relationship between rate of drug uptake in brain and behavioral pharmacology of monoamine transporter inhibitors in rhesus monkeys. Pharmacol Biochem Behav 90:453-462

Kleven MS, Anthony EW, Woolverton WL (1990) Pharmacological characterization of the discriminative stimulus effects of cocaine in rhesus monkeys. J Pharmacol Exp Ther 254:312-317

Koe BK (1976) Molecular geometry of inhibitors of the uptake of catecholamines and serotonin in synaptosomal preparations of rat brain. J Pharmacol Exp Ther 199:649-661

Kosten TA, Kosten TR (1989) Cocaine abuse and opioid withdrawal. Lancet 2:165-166

Kotian P, Abraham P, Lewin AH, Mascarella SW, Boja JW, Kuhar MJ, Carroll FI (1995) Synthesis and ligand binding study of 3 beta(4 $\phi$-substituted phenyl)-2 beta-(heterocyclic)tropanes. J Med Chem 38:3451-3453

Lawford BR, Young RM, Noble EP, Sargent J, Rowell J, Shadforth S, Zhang X, Ritchie T (2000) The $\mathrm{D}_{2}$ dopamine receptor A1 allele and opioid dependence: association with heroin use and response to methadone treatment. Am J Med Genet B Neuropsychiatr Genet 96:592-598

Lindsey KP, Wilcox KM, Votaw JR, Goodman MM, Plisson C, Carroll FI, Rice KC, Howell LL (2004) Effects of dopamine transporter inhibitors on cocaine self-administration in rhesus monkeys: relationship to transporter occupancy determined by positron emission tomography neuroimaging. J Pharmacol Exp Ther 309:959-969
McMahon LR, Sell SL, France CP (2004) Cocaine and other indirectacting monoamine agonists differentially attenuate a naltrexone discriminative stimulus in morphine-treated rhesus monkeys. J Pharmacol Exp Ther 308:111-119

Paronis CA, Woods JH (1997) Ventilation in morphine-maintained rhesus monkeys. I: effects of naltrexone and abstinence-associated withdrawal. J Pharmacol Exp Ther 282:348-354

Redmond DE, Krystal JH (1984) Multiple mechanisms of withdrawal from opioid drugs. Annu Rev Neurosci 7:443-478

Rosen MI, Wallace EA, Sullivan MC, Stine S, Kosten TR (1992) Use of cocaine to prevent opiate withdrawal. Am J Psychiatry 149:1609

Sell SL, France CP (2002) Cocaine and amphetamine attenuate the discriminative stimulus effects of naltrexone in opioid-dependent rhesus monkeys. J Pharmacol Exp Ther 301:1103-1110

Sell SL, McMahon LR, Koek W, France CP (2005) Monoaminergic drugs and directly observable signs of LAAM withdrawal in rhesus monkeys. Behav Pharmacol 16:53-58

Sinnott RS, Mach RH, Nader MA (1999) Dopamine $\mathrm{D}_{2} / \mathrm{D}_{3}$ receptors modulate cocaine's reinforcing and discriminative stimulus effects in rhesus monkeys. Drug Alcohol Depend 54:97-110

Tang AH, Code RA (1989) Studies on the discriminative stimulus properties of apomorphine in rhesus monkeys. Psychopharmacology 97:418-422

Tseng LF, Brase DA, Loh HH (1976) Dopaminergic influence on withdrawal jumping behavior in morphine-dependent mice. Res Commun Chem Pathol Pharmacol 15:435-446

Walters CL, Aston-Jones G, Druhan JP (2000) Expression of fosrelated antigens in the nucleus accumbens during opiate withdrawal and their attenuation by a $\mathrm{D}_{2}$ dopamine receptor agonist. Neuropsychopharmacology 23:307-315

Wilcox KM, Lindsey KP, Votaw JR, Goodman MM, Martarello L, Carroll FI, Howell LL (2002) Self-administration of cocaine and the cocaine analog RTI-113: relationship to dopamine transporter occupancy determined by PET neuroimaging in rhesus monkeys. Synapse 43:78-85

Wise RA, Leone P, Rivest R, Leeb K (1995) Elevations of nucleus accumbens dopamine and DOPAC levels during intravenous heroin self-administration. Synapse 21:140-148

Woolverton WL, Goldberg LI, Ginos JZ (1984) Intravenous selfadministration of dopamine receptor agonists by rhesus monkeys. J Pharmacol Exp Ther 230:678-683

Woolverton WL, Kamien JB, Goldberg LI (1987) Pharmacological analysis of the apomorphine discriminative stimulus in rhesus monkeys. J Pharmacol Exp Ther 241:213-217

Zarrindast MR, Habibi M, Borzabadi S, Fazli-Tabaei S, Hossein Yahyavi S, Rostamin P (2002) The effects of dopamine receptor agents on naloxone-induced jumping behaviour in morphinedependent mice. Eur J Pharmacol 451:287-293 